\title{
Extraadrenalis glükokortikoidszintézis
}

\author{
Szappanos Ágnes dr. ${ }^{1,3}$ - Mészáros Katalin ${ }^{4}$ \\ Nagy Zsolt ${ }^{1,4}$ - Kövesdi Annamária ${ }^{1}$ - Likó István ${ }^{4}$ - Kiss Emese dr. ${ }^{3}$ \\ Tóth Miklós dr. ${ }^{1}$. Patócs Attila dr. ${ }^{2,4}$ \\ Semmelweis Egyetem, Általános Orvostudományi Kar, ${ }^{1}$ II. Belgyógyászati Klinika, \\ ${ }^{2}$ Laboratóriumi Medicina Intézet, Budapest \\ ${ }^{3}$ Országos Reumatológiai és Fizioterápiás Intézet, Budapest \\ ${ }^{4}$ Magyar Tudományos Akadémia-Semmelweis Egyetem, \\ „Lendület” Örökletes Endokrin Daganatok Kutatócsoport, Budapest
}

\begin{abstract}
Az endogén glükokortikoidok az anyagcsere-folyamatok szabályozása mellett, immunmoduláns és immunszuppreszszív hatásukon keresztül, kiemelt jelentőségűek a szövetszintü gyulladásos reakciókban. A szervezet endogén kortizolszabályozása kétféle mechanizmuson keresztül valósul meg. A szisztémás szabályozásért a hypothalamushypophysis-mellékvese tengely, míg a lokális, szövetspecifikus glükokortikoidszabályozásért a kortizol biológiai hatását közvetítő glükokortikoidreceptor, illetve a prereceptoriális szinten ható, a sejtek glükokortikoidellátását biztosító, $11 \beta$-hidroxi-szteroid-dehidrogenáz enzim felelős. A legújabb kutatási eredmények alapján a mellékvesén kívül egyéb szövetek is képesek biológiailag aktív kortikoszteroidok bioszintézisére, amelyek kiemelt jelentőségúek a szövetspecifikus glükokortikoidhatás szabályozásában. Az extraadrenalis kortikoszteroidok szintéziséhez szükséges enzimek jelenlétét napjainkig már igazolták a bőrben, a bélben és a thymusban, valamint jelenlétük feltételezhető a központi idegrendszerben, a cardiovascularis rendszerben és a tüdőben. A de novo szteroidszintézis szabályozásában az autokrin és a parakrin jelátviteli rendszeren keresztül megvalósuló lokális szabályozási hurkok feltételezhetők. Jelentôségük felmerül a szövetszintű homeosztázis fenntartásában és immunológiai folyamatok szabályozásában.
\end{abstract}

Orv Hetil. 2018; 159(7): 260-268.

Kulcsszavak: kortizol, szövetspecifikus glükokortikoidszabályozás, de novo kortikoszteroidszintézis

\section{Extraadrenal glucocorticoid synthesis}

Endogenous glucocorticoids exert a diverse array of physiological processes and play an important role in immune modulatory and anti-inflammatory responses. The secretion of cortisol by the adrenal gland is regulated through two mechanisms. Systemic regulation is substantiating by the hypothalamo-pituitary-adrenal axis. Furthermore, a tissuespecific local regulatory system, containing the $11 \beta$-hydroxysteroid dehydrogenase enzyme responsible for local glucocorticoid synthesis and the glucocorticoid receptor, has also been demonstrated. Based on the recent evidences, an extra-adrenal corticosteroid synthesis exists in various tissues. Steroidogenic enzymes necessary for this de novo corticosteroid synthesis have been observed in the skin, intestine, thymus and possibly in the brain, heart and lung. These locally synthesized steroids most likely act in an autocrine and paracrine manner and their regulation is mediated by local regulatory loops. The importance of this de novo corticosteroid synthesis seems to be important in the regulation of local homeostasis, immune processes and tissue-specific inflammatory reactions.

Keywords: cortisol, tissue-specific glucocorticoid regulation, de novo corticosteroid synthesis

Szappanos Á, Mészáros K, Nagy Zs, Kövesdi A, Likó I, Kiss E, Tóth M, Patócs A. [Extraadrenal glucocorticoid synthesis]. Orv Hetil. 2018; 159(7): 260-268.

(Beérkezett: 2017. december 10.; elfogadva: 2018. január 11.)

\section{Rövidítések}

$3 \beta$-HSD = 3 $\beta$-hidroxi-szteroid-dehidrogenáz/izomeráz; ACTH $=$ adrenokortikotrop hormon; $\mathrm{Bcl} 2=\mathrm{B}$-sejtes lymphoma-2; $\mathrm{cAMP}=$ ciklikus adenozin - monofoszfát $; \mathrm{CRH}=($ corticotro - pin-releasing hormon) kortikotropinfelszabadító hormon; $C Y P 2 D=$ a $\mathrm{P} 4502 \mathrm{D}$ enzimet kódoló gén; CYP1IA1 = a P450 ssc -enzimet kódoló gén; CYPI1B1 = a P450 $11_{\text {beta }}$-enzimet kódoló gén; CYP11B2 = a P450 11 AS-enzimet kódoló 
gén; CYP17 = a P450 17 -enzimet kódoló gén; CYP21 = a P450 21-enzimet kódoló gén; $\mathrm{DN}=$ (double negative) kettős negatív; $\mathrm{DP}=($ double positive $)$ kettős pozitív; $\mathrm{GR}=$ glükokortikoidreceptor; HPA $=$ (hypothalamic-pituitary-adrenal) hypothalamus-hypophysis-mellékvese; HSDl $1 \mathrm{~B}=11 \beta$-hidroxiszteroid-dehidrogenáz enzim; IL1 $\beta=$ interleukin- $1-\beta ;$ LDL $=$ (low density lipoprotein) alacsony sürüségű lipoprotein; LPS = lipopoliszacharid; $\mathrm{LRHI}=$ máj-homológ-1-receptor; $\mathrm{MHC}=$ major histocompatibility complex; MLN64 = metastatic lymph node; $\mathrm{mRNS}=$ (messenger) hírvivő ribonukleinsav; P450 2D = citokróm P450 2D enzim; P450 11 AS = aldoszteron-szintáz; $\mathrm{P} 450_{\mathrm{c}} 1 \mathrm{l}_{\text {beta }}=$ szteroid-11 $\beta$-hidroxiláz; $\mathrm{P} 450_{\mathrm{c}} 17=$ citokróm P450 17 enzim/szteroid $17 \alpha$-hidroxiláz/17,20-liáz enzim; $\mathrm{P} 450 \mathrm{c} 21$ = szteroid-21-hidroxiláz; $\mathrm{P} 450_{\mathrm{ssc}}=$ koleszterinoldallánc-hasító enzim; POMC $=$ proopiomelanokortin; $\mathrm{SP}=$ (single positive) egyszeresen pozitív; StAR = szteroidogenezist akutan reguláló fehérje; TCR $=$ T-sejt-receptor; Thl = thymus helper- 1 ; TNF $\alpha=$ tumornekrózisfaktor- $\alpha$; TNFR = tumornekrózisfaktor-receptor

A mellékvesekéreg által szintetizált endogén glükokortikoidok élettani hatásai rendkívül szerteágazóak. Az anyagcsere-folyamatok szabályozása mellett, fiziológiás körülmények között, immunmoduláns szerepet töltenek be a gyulladásos folyamatok szövetszintű szabályozásában, valamint gyulladásgátló, immunszuppresszív hatással is rendelkeznek. A mesterséges úton előállított glükokortikoidokat napjaink leghatásosabb gyulladáscsökkentó szereiként, gyulladásos és autoimmun megbetegedésekben a gyógyszeres kezelés első lépéseként alkalmazzák [1].

\section{Szisztémás és szövetspecifikus glükokortikoidszabályozás}

A szervezet endogén glükokortikoidszabályozása kétféle mechanizmuson keresztül valósul meg. A szisztémás szabályozás részeként, a mellékvesekéreg által a keringésbe juttatott kortizol - rágcsálókban kortikoszteron - menynyiségét a hypothalamus-hypophysis-mellékvese (HPA-) tengely múködése határozza meg. Egy kevésbé ismert, autokrin/parakrin jelátviteli rendszeren keresztül megvalósuló, szövetspecifikus glükokortikoidszabályozásért pedig a kortizol biológiai hatását közvetítő glükokortikoidreceptor (GR), illetve a sejtek glükokortikoidellátását biztosító 11ß-hidroxi-szteroid-dehidrogenáz enzim (HSD11B) felelős. Prereceptoriális szinten a glükokortikoidellátottság meghatározásában a HSDl1B-enzim két izoformája vesz részt. A HSDl1Bl-enzim a hormonálisan inaktív kortizont hormonálisan aktív kortizollá alakítja át, míg a HSD11B2-enzim a kortizol inaktiválását végzi [2]. A glükokortikoidhatás közvetítéséért felelős GR-izoformák alternatív splicing, alternatív transzláció és poszttranszlációs módosulások útján képesek a szövetspecifikus glükokortikoidérzékenységet befolyásolni. A szisztémás és a szövetspecifikus szabályozásban részt vevő molekulák egyes genetikai eltérései mellett a fehérjék múködéséhez szükséges kofaktorok ellátottsága is szerepet játszik az egyéni glükokortikoidérzékenység kialakításában [3].

Eddigi ismereteink alapján a biológiailag aktív, keringésbe juttatott kortikoszteroidok (mineralo- és glükokortikoidok) bioszintézisének helyszíne a mellékvesekéreg zona glomerulosa és zona fasciculata rétege. Az elmúlt évtized kutatási eredményei azonban kimutatták, hogy a mellékvesén kívül, a szteroid-bioszintézis szubsztrátjából, a koleszterinből kiindulva egyéb szövetek is képesek de novo kortikoszteroidszintézisre $[4,5]$. A bioszintézishez szükséges enzimek és szabályozási mechanizmusok a különböző fajokban és szövetekben nagyfokú egyedi eltérést mutatnak; napjainkig a thymusban, a bélben, a bőrben, a központi idegrendszerben, a tüdőben és a cardiovascularis rendszerben igazolták ezeknek az enzimeknek a jelenlétét. $\mathrm{Az}$ extraadrenalis kortikoszteroidoknak a patofiziológiai és glükokortikoidszabályozásban betöltött szerepét részleteiben még nem tisztázták, de felmerül a jelentőségük autokrin és parakrin jelátviteli rendszereken keresztül a lokális homeosztázis és a szövetszintű immunológiai folyamatok szabályozásában.

\section{Intraadrenalis kortikoszteroid-bioszintézis}

A mellékvesekéreg zona glomerulosa és zona fasciculata rétegében képződő, biológiailag aktív aldoszteron, kortikoszteron és kortizol szintéziséhez szükséges koleszterin fő forrását elsősorban a plazma LDL- (alacsony sưrûségú lipoprotein) frakciója biztosítja, amelyból lizoszomális észterázok hatására szabad koleszterin képződik. A koleszterin bejutását a mitokondrium belső membránjára a StAR-fehérje (szteroidogenezist akutan reguláló fehérje) biztosítja, ahol a hormonszintézis első lépéseként a citokróm P450 oxidálóenzimek családjába tartozó, koleszterinoldallánc-hasító enzim $\left(\mathrm{P}_{450} \mathrm{ssc}_{\mathrm{sc}}\right)$ hatására a koleszterin pregnenolonná alakul át [6]. A szteroid-bioszintézis első lépésének további kiemelt jelentőségét az adja, hogy mind a StAR-fehérje, mind a $\mathrm{P}^{4} 50_{\text {ssc }}$-enzim mennyisége az adrenokortikotrop hormon $(\mathrm{ACTH})$ szabályozása alatt áll. A bioszintézis következő lépései során az egyes szubsztrátmolekulák átalakulását a citokróm $\mathrm{P} 450$ oxidálóenzimek családjába tartozó monooxigenázok és hidroxi-szteroid-dehidrogenázok végzik (az aldoszteron bioszintézisében: $\mathrm{P} 450_{\mathrm{ssc}}$, 3 $\beta$-HSD, P450 $21, \mathrm{P} 450_{\mathrm{c}} 11 \mathrm{AS}$; a kortizol bioszintézisében: $\mathrm{P} 450_{\text {ssc }}, \mathrm{P} 450_{\mathrm{c}} 17,3 \beta$-HSD, $\mathrm{P} 450_{\mathrm{c}} 21, \mathrm{P} 450_{\mathrm{c}} 11_{\text {beta }}$; a kortikoszteron bioszintézisében: $\mathrm{P} 450_{\mathrm{ssc}}, 3 \beta-\mathrm{HSD}$, $\mathrm{P} 450$ 21, P450 11 AS (1. ábra).

\section{Mellékvesekérgen kívüli, de novo kortikoszteroid-bioszintézis}

\section{Bör}

A bőr közvetítő szerepet tölt be a külső és a belső környezet között. Barrierként fontos szerepet játszik a belső 


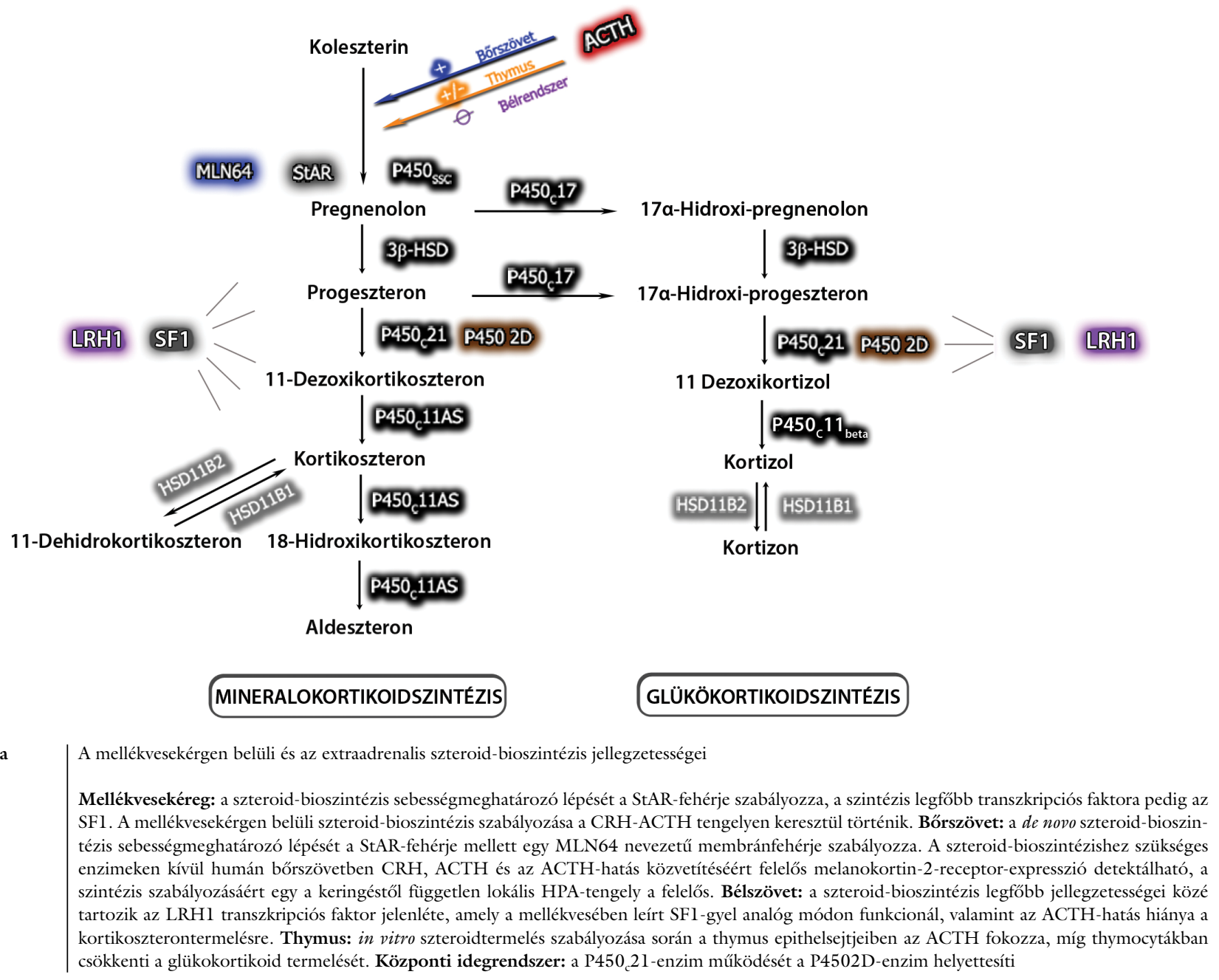

környezet dinamikus állandóságának fenntartásában és immunológiai folyamatok szabályozásában.

A szteroid-bioszintézis enzimeit tekintve, egerek bőrszövetében kimutatható a CYPIIAl-expresszió, azonban a pregnenolon további szteroidszubsztrát-molekulákká történő átalakulása nem igazolható. Patkányban a glükokortikoid-bioszintézishez szükséges enzimek jelenléte ellenére a CYPIIAl-enzim nem expresszálódik. A de novo szteroidtermelés-szabályozásért felelős hormonok közül egerek bőrében a kortikotropinfelszabadítóhormon (CRH)-fehérje hírvivő ribonukleinsav (mRNS) expressziója nélkül mutatható ki, ami a fehérje bőrszöveten kívüli eredetére utal $[4,5]$.

Humán epidermisben, szőrtüszőkben, dermalis fibroblastokban, melanocytákban, faggyúmirigyben és in vitro keratinocytákban a kortizolszintézishez szükséges összes enzim jelenlétét igazolták $\left(\mathrm{P}_{450} 0_{\mathrm{ssc}}, \mathrm{P} 450_{\mathrm{c}} 17\right.$, $3 \beta$-HSD, P450 $\left.21, P 450_{c} 11_{\text {beta }}\right)$ mRNS- és fehérjeexpressziós vizsgálatok alapján $[4,5]$. Egészséges emberi bőrszövetben a StAR-fehérje mellett metastatic lymph node (MLN64) nevü, StAR-homológ koleszterintranszporter membránfehérje jelenlétét is detektálták [7]. Hannen és mtsai psoriasisban és atopiás dermatitisben szenvedő betegekben alacsony StAR- és MLN64-ex- pressziót találtak, ami felveti a csökkent lokális, de novo kortizoltermelés lehetőségét ezekben a kórállapotokban [8]. A szteroid-bioszintézishez szükséges enzimeken kívül, humán bőrszövetben a CRH-, az ACTH- és az ACTH-hatás közvetítéséért felelős melanokortin-2-receptor-expresszió is megfigyelhető [9]. Melanocytákon, szőrtüszőkön és fibroblastokon végzett vizsgálatok a CRH-ACTH tengely hatására fokozódó kortizolszekréciót, valamint negatív visszacsatolás útján kortizolhatásra csökkenő CRH-válaszreakciót igazoltak [5].

Mechanikai sérülések, kórokozó ágensek behatolása vagy UV sugárzás következtében kialakult patológiás állapotok glükokortikoidszintézist indukálnak a bőrben a gyulladásos folyamatok aktiválásán keresztül. A tumornekrózisfaktor- $\alpha(\mathrm{TNF} \alpha)$, az interleukin-1- $\beta$ (ILl $\beta$ ) és a szintén proinflammatorikus hatással rendelkező CRH az ACTH stimulációján keresztül - lokális glükokortikoidszintézist okoz. Ugyanakkor az így termelődött kortizol negatív visszacsatolás útján - a CRH és proinflammatorikus citokinek gátlásán keresztül - képes csökkenteni a gyulladásos folyamatok mértékét $[4,5]$.

Kutatási eredmények igazolták a lokálisan szintetizált glükokortikoidok sebgyógyulásban betöltött szerepét is. Vukelic és mtsai a bőrben szintetizált glükokortikoidok 
metiraponnal történt gátlásával a sebgyógyulás mértékének gyorsulását figyelték meg. Emellett a sebgyógyulás akut fázisában a kortizolszintézist negatív visszacsatolás útján szabályozó HSD11B2-enzim fokozott múködését igazolták [10]. Ezzel párhuzamosan a hormonálisan inaktív kortizon hormonálisan aktív kortizollá történő átalakításáért felelős HSDIlBl-enzim gátolta a sejtproliferációt és a sebgyógyulást, emellett expressziója az életkor előrehaladásával és a testsúllyal arányosan nőtt [11]. Egy másik tanulmányban kimutatták, hogy a GR keratinocytákban történő túlzott expressziója a glükokortikoidok iránti érzékenység növekedését és elhúzódó sebgyógyulást idézett elö [12].

A bőrszövetben megfigyelhető de novo glükokortikoidszintézis egy a keringéstől független, lokális $\mathrm{CRH}$ ACTH-kortizol/citokin-CRH-ACTH-kortizol rendszer szabályozása alatt áll. A bőrben képződött glükokortikoidnak - a szöveten belüli gyulladásos folyamatok szabályozásában és a homeosztázis fenntartásában betöltött funkciója alapján - terápiás szerepe lehet egyes bőrgyógyászati kórállapotok és bőrérintettséggel járó autoimmun folyamatok gyógyításában.

\section{Bélrendszer}

A mechanikai, felszívó és szekréciós funkcióval rendelkező bélrendszer, a bőrszövethez hasonlóan, kiemelt szerepet tölt be a külső és a belső környezet közötti barrier kialakításában. Emellett az emberi mikrobiom legnagyobb részét alkotó bélflórának köszönhetően a celluláris, humorális és nem specifikus immunrendszer szabályozásán keresztül, bélrendszerünk a szervezet legfőbb immunszervének tekinthető. A bélflóra összetételének megváltozása szerepet játszhat számos kórállapot, elsősorban a gyulladásos bélbetegségek kialakulásában. E kóros folyamatban fontos szerepe lehet a lokális glükokortikoidképzés rendellenességének is.

A de novo glükokortikoid szintéziséhez szükséges enzimek mRNS- és fehérjeexpresszióját bélszövetben elsőként egérembriókban, majd rágcsálók vékony- és vastagbelében igazolták $[4,5]$, de az egyes enzimek expressziójának nagyfokú variabilitása figyelhetó meg. A rágcsálók bélrendszerében a CYPIIAI-enzim expreszsziója a proximalis vékonybéltól a vastagbélig fokozatos csökkenést mutat. A szteroid-bioszintézishez szükséges enzimek jelenléte a cryptákban található proliferációs epithelsejtekre korlátozódik, valamint az éretlen epithelsejtek érett, proliferációra nem képes sejtekké történő differenciálódása az egyes enzimek mRNS-ének csökkenését okozza $[13,14]$. Humán vastagbél-biopsziás mintákból is kimutattak CYPIIA1- és CYPIlB2-expressziót, ami a humán bélrendszer de novo glükokortikoidszintézisének képességére utal [15].

A szteroid-bioszintézishez szükséges enzimek aktivitása összefüggést mutat az immunrendszer aktiválódásával és gyulladásos folyamatok kialakulásával. Az intestinalis de novo glükokortikoidszintézist thymus helper-l (Thl-) sejtes immunválasz aktivációja váltja ki. A rágcsálók bélrendszerében virális infekció, metiraponnal történt előkezelés után az in vivo adott anti-CD3-antitest következtében kialakult T-sejt-aktiváció, valamint veleszületett immunrendszer lipopoliszachariddal (LPS) történő aktivációja a de novo glükokortikoidszintézis fokozódásához és a kortikoszteronszint emelkedéséhez vezetett [14, 16]. További kutatási eredményekben a kortikoszteronszintézishez szükséges enzimek folyamatos jelenléte mellett, T-sejt-aktivációt vagy gyulladásos reakciót követően, a CYPIIA1- és a CYPIIBI-expresszió fokozódását mutatták ki [5]. TNF $\alpha$ - vagy tumornekrózisfaktorreceptor (TNFR)-deficiens egerekben az immunrendszer aktivációja után a fokozott intestinalis glükokortikoidszintézis elmaradt, aminek alapján a TNF $\alpha$-ának elsődleges szerepe lehet ezeknek a folyamatoknak az indukciójában [16]. A bélrendszerben de novo szintetizált glükokortikoidoknak a lokális immunfolyamatok szabályozásában betöltött szerepére utal, hogy a szisztémás vagy az extraadrenalis glükokortikoidszintézisnek adrenalectomiával vagy metiraponnal történő gátlása károsodott T-sejt-aktivációt okozott [14].

A bélszöveten belüli kortikoszteroid-bioszintézis szabályozása több lépésben is eltérést mutat a mellékvesekéregben megfigyelt szabályozáshoz képest. A szabályozás egyik jellegzetessége, hogy mellékvesekéreg-sejtvonalakban a ciklikus adenozin-monofoszfát (cAMP) a CYPIIAl és a CYPIIBI mRNS-szintjének fokozódásához vezetett, míg intestinalis epithelsejtekben a glükokortikoidszintézist csökkentette [17]. Ezzel párhuzamosan, ACTH hatására a mellékvese által termelt kortikoszteron szintjének fokozódását mutatták ki, míg az intestinalis kortikoszterontermelést az ACTH nem befolyásolta. Mindezt alátámasztja, hogy bélszövetben az ACTH prekurzor, proopiomelanokortin (POMC)expressziója nem detektálható [17]. A cAMP és az ACTH lokális bioszintézisre kifejtett hatásaival ellentétben a proteinkináz-aktiváció mellékvesesejtekben a CYPIIB1-enzim transzkripcióját nem befolyásolta, míg intestinalis epithelsejtekben a transzkripciót fokozta [17]. Végezetül, a mellékvesekéregben a glükokortikoidszintézis legfőbb transzkripciós faktora a szteroidogenezisfaktor-1 (SFl), míg bélszövetben ugyanezt a feladatot a máj-homológ-1-receptor (LRHI) látja el [18]. Az LRHI-nek a sejtciklus szabályozásában betöltött szerepére utal, hogy - a de novo glükokortikoidszintézis enzimeihez hasonlóan - a cryptákban található, proliferációs aktivitást mutató epithelsejtekben expresszálódik [13]. Emellett kiemelt jelentősége van a bélrendszer lokális gyulladásos válaszreakcióinak és immunológiai folyamatainak szabályozásában is. Colitis ulcerosában és Crohn-betegségben szenvedők vastagbél-biopsziás mintáiban Coste és mtsai csökkent LRHl-expressziót és de novo glükokortikoidszintézist találtak [15]. Emellett LRHl-haploinsufficiens egerekben az LRHI-mediált glükokortikoidszintézis védelmet jelentett az experimentális colitissel szemben [15]. 


\section{Thymus}

\section{A glïkokortikoidoknak a T-sejtek érésében betöltött szerepe}

A thymocytáknak a csontvelői progenitor T-sejtekből érett, immunkompetens T-sejtekké való átalakulása a csecsemőmirigyben történik. Ezen komplex érési folyamat során megtörténik a funkcióképtelen és az autoreaktív T-sejtek eliminációja, illetve az érett, naiv T-sejteknek a perifériás véráramba jutása. A T-sejt-repertoár kialakításához nélkülözhetetlen a thymus felépítésében szerepet játszó epithelsejtek hálózata és a stromasejtek jelenléte, melyek direkt sejt-sejt kontaktus és humorális faktorok által közvetített anti- és proapoptotikus jelek segítségével képesek a thymocyták érési folyamatát szabályozni. A humorális egységek közé tartozó citokinek és hormonok közül kiemelt jelentőségű a glükokortikoidok jelenléte.

A tartós stresszhelyzet vagy szteroidterápia következtében megnövekedett glükokortikoidszint a thymus involúcióját eredményezi, elsősorban a kettős pozitív (DP-) thymocyták apoptózisán keresztül [19]. Ezzel ellentétben, a legújabb kutatási eredmények alapján a glükokortikoidok fontos szerepet játszanak a T-sejtek differenciálódásában és túlélésében is. A thymocyták önálló glükokortikoidtermelésének felismerése vezetett a kölcsönös antagonizmus elméletének kidolgozásához, amely szerint a DP-thymocyták pozitív és negatív szelekciójában a T-sejt-receptor (TCR) ligandkötésének affinitásán kívül a glükokortikoidok által indukált jelátviteli útvonalak is szerepet játszanak. A modell szerint a glükokortikoidhatás elősegíti a sejtek túlélését az egyébként negatív szelekció által apoptózisra ítélt thymocytákban, a thymocytát a TCR-en és a GR-en keresztül egyszerre ért jelátviteli utak közötti kölcsönhatások eredőjén keresztül. A DP-thymocyták túlélésében szerepet játszó TCR-GR közötti kölcsönhatás molekuláris mechanizmusa részleteiben nem ismert. Felmerül az antiapoptotikus $\mathrm{Bcl} 2$ (B-sejtes lymphoma-2) gén szerepe és a GR interakciója az APl-, a NFAT- és a NF- $\nprec$ B-molekulákkal. Ezeken kívül a MAPKs-, a PKB- és a PKC-molekulák foszforilációja és az Lck- és Fyn-kináz-molekulák glükokortikoidok általi gátlása is szerepet játszhat a kölcsönhatás kialakításában [20] (2. ábra).

\section{Lokális glïkokortikoidszintézis a thymusban}

A thymusban de novo termelődő glükokortikoidok jelenlétét elsőként egerek, majd később rágcsálók epithelsejtjeiben és thymocytáiban igazolták. A P450 17-enzim aktivitásának hiányában a szteroidszintézis végterméke ezen esetekben a kortikoszteron. Csirkék csecsemőmirigyében a $\mathrm{P} 450_{\mathrm{ssc}^{-}}$, a $\mathrm{P} 450_{\mathrm{c}} 1 \mathrm{l}_{\text {beta }^{-}}$, a $3 \beta$-HSD- és a $\mathrm{P} 450 \mathrm{c} 21$-enzim mellett a P450 17 -aktivitás is megfigyelhető, ami a mellékveséjükben szintetizálódó kortikoszteronnal ellentétben a thymus kortizolszintézisére utal. Mindemellett madarakban a de novo szteroidogenezis-

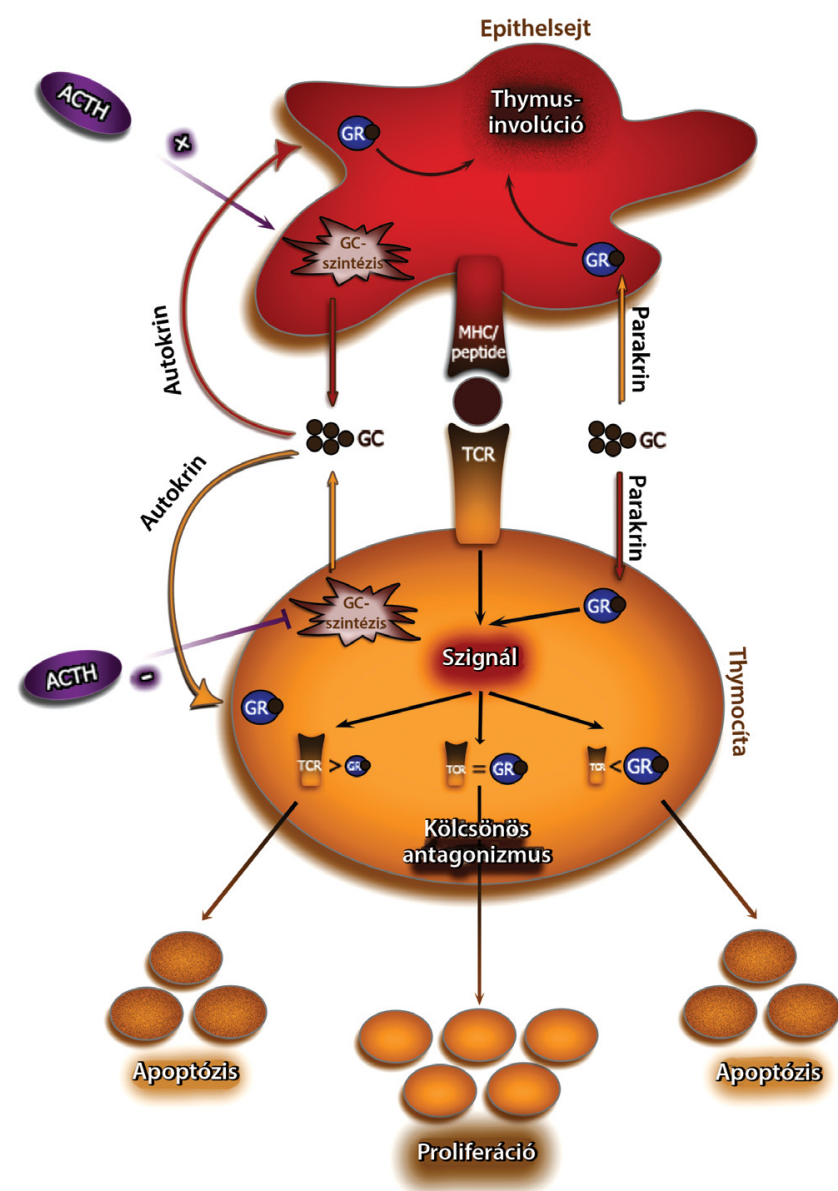

2. ábra De novo glükokortikoidszintézis a thymusban
A thymusban a lokálisan termelődő glükokortikoidok jelenléte
epithelsejtekben és CD4+-, CD8+-DP-thymocytákban igazol-
ható. Az epithelsejtekben a de novo glükokortikoidszintézis
mértéke születéskor, míg thymocytákban a pubertás alatt a leg-
magasabb. ACTH hatására epithelsejtekben az in vitro szteroid-
termelés fokozódik, míg thymocytákban csökken. Mind az
epithelsejtekben, mind a thymocytákban termelődő glüko-
kortikoidok, a GR-t ért parakrin és autokrin útvonalakon ke-
resztül, képesek a thymocyták érési folyamatát befolyásolni, a
TCR saját MHC-peptid-komplex iránti affinitásának szabályo-
zásával. Az alacsony GR-szignállal és a saját MHC-peptid-
komplex iránt erós affinitású TCR-rel rendelkezó thymocyták
negatív szelekción keresztül apoptózissal elpusztulnak. Magas
glükokortikoidkoncentráció esetén a GR-szignál erőssége meg-
haladja a TCR-szignál erósségét, ami szintén apoptózishoz, a
sejtek pusztulásához vezet. A kölcsönös antagonizmus elmélete
szerint az apoptózisra ítélt magas affinitású TCR-szignállal ren-
delkező thymocytákban mérsékelt koncentrációban jelen lévő́
glükokortikoidok képesek a proapoptotikus jelek ellensúlyozá-
sára, biztosítva ezzel az egyébként negatív szelekcióra ítélt
thymocyták túlélését. Mindezen túl a thymusban de novo képző-
dő glükokortikoidok jelentósége felmerül a thymus involúciójá-
nak patomechanizmusában

hez szükséges enzimeket az emlősök csontvelőjével analóg bursa Fabricii-ben is igazolták. Zebrapintyek esetében a thymusban és a bursa Fabricii-ben az elsődleges glükokortikod a kortizol, ellentétben a perifériás keringésükben jelen lévő kortikoszteronnal, ami a lymphoid szövetek és a mellékvese eltérő glükokortikoid-bioszintézisére utal $[4,5]$. 
Patkányokon, rágcsálókon és madarakon végzett kísérletek alapján a thymusban végbemenő de novo kortikoszteroidszintézis szabályozása egy, a HPA-tengellyel analóg lokális szabályozórendszeren keresztül történik. Humán thymusban ACTH-aktivitást igazoltak, míg patkány- és madárthymusban mind az ACTH-, mind a CRH-immunreaktivitás kimutatható volt [21, 22]. Rágcsálók thymus-epithelsejtjeiben az ACTH fokozta [23], míg a thymocytáiban csökkentette az in vitro szteroidtermelést [24], aminek a lokális glükokortikoidegyensúly fenntartásában tulajdonítanak szerepet. Mindemellett a thymocytákban a tesztoszteron is szerepet játszik a de novo szteroidogenezis szabályozásában: tesztoszteron adása a thymus involúcióját eredményezte, párhuzamosan a szteroidogenezis-enzimek expressziójának fokozódásával és a lokális glükokortikoidszintek emelkedésével [25].

A thymusban de novo végbemenő szteroidogenezis intenzitására jellemző, hogy eltérő mértékben változik az életkor elörehaladtával, mind egy adott sejtcsoporton belül, mind pedig az egyes sejtcsoportok között. Egerek és zebrapintyek epithelsejtjeiben a lokálisan termelt glükokortikoidok szintje születéskor a legmagasabb, majd az életkorral csökken $[26,27]$. Ennek az életkorhoz kapcsolódó változásnak a jelentősége felmerült az úgynevezett stressz hiporeszponzív periódus következtében kialakult, csökkent perifériás kortizoltermelés kompenzálásában. A születés utáni időszakban - átmenetileg csökkent szisztémás kortizoltermelés mellett - a lokális kortizoltermelés biztosíthatja a lymphoid szervekben megfigyelhető magas glükokortikoidszintet. Az epithelsejtekkel ellentétben, a thymocytákban pubertás alatt magasabb volt a de novo glükokortikoidszintézis mértéke a születéskor mért értékekhez viszonyítva [26]. A thymocyták glükokortikoidtermelése nemcsak életkor függő, hanem a thymocyták fejlődési stádiumával is öszszefüggést mutat. A kortikoszterontermelés a DP-sejtekben volt kimutatható, az egyszeresen pozitív (SP) thymocyták és a perifériás T-sejtek glükokortikoidot nem szintetizáltak [26] (2. ábra). Ennek a thymocyták korával és érési stádiumával összefüggést mutató glükokortikoidszintézisnek tulajdonítanak szerepet a pubertáskor alatt kezdődő thymusinvolúcióban [28].

\section{Központi idegrendszer}

Az agyban lokálisan képződő „neuroszteroidok” létezése patkányokon végzett kísérletek alapján az 1980-as évek eleje óta ismert [29]. Az agyszövetben végbemenő szteroid-bioszintézis nagyfokú egyéni és faji diverzitással jellemezhető, melynek funkcionális jelentősége mind ez idáig nem ismert. Patkányok agyában a koleszterinből de novo képződő glükokortikoidok és mineralokortikoidok szintéziséhez szükséges összes enzim mRNS expressziója kimutatható. Ugyanakkor a mellékvesekéregben és egyéb extraadrenalis szövetben történő bioszintézishez képest a patkányok agyszövete alacsony CYP21-mRNS- expresszióval jellemezhető. Ebben az esetben a 21-hidroxiláz enzim funkcióját egy P450 2D nevú alternatív enzim helyettesíti [30]. A lokális szteroidszintek vizsgálata során, intakt patkányok agyszövetében alacsonyabb kortikoszteronszintet mértek a plazmához viszonyítva, ami a szisztémás kortikoszteron vér-agy gáton történő elégtelen átjutására és a glükokortikoidok egyes agyterületekre kifejtett károsító hatása elleni védelemre utal. Ezzel ellentétben adrenalectomiával kezelt patkányok agyszövetében, a vérplazmához viszonyítva, emelkedett aldoszteronszint volt kimutatható, ami lokális aldoszteron-bioszintézisre utal [31]. A lokális aldoszteronbioszintézis szabályozásának vizsgálata során az alacsony nátriumbevitel mind az agyszövetben, mind a mellékvesében fokozta a CYPIIB2-mRNS-expressziót [32]. Emellett patkányok agyszövetében a klasszikus reninangiotenzin rendszer összes komponensének jelenlétét igazolták [33]. Egerekben szintén kimutatható a szteroidbioszintézishez szükséges összes enzim jelenléte, a CYPIIBI és a CYPIIB2 alacsony mRNS-szintje mellett [34]. Patkányokkal ellentétben, adrenalectomiával kezelt egerek agyszövetében a kortikoszteroidok szintje emelkedett a plazmához viszonyítva, ami a lokális kortikoszteron-bioszintézist igazolja. Patkányok és egerek mellett énekesmadarak agyszövetében is vizsgálták a lokálisan képződő szteroidok szintjét, és az egerekhez hasonlóan az agyban magasabb glükokortikoidkoncentrációt mértek a plazmához viszonyítva [27]. Humán agyszövetben kimutatható a glükokortikoid- és mineralokortikoidszintézishez szükséges összes enzim jelenléte, ugyanakkor, patkányokhoz hasonlóan, a P450 21-enzim (21-hidroxiláz) múködését itt is a P450 2D enzim helyettesíti [30].

A faji különbségek mellett, az agyszövetben végbemenő de novo kortikoszteroid-bioszintézis az egyes agyterületek tekintetében is nagyfokú variációt mutat. Az agyi régiók eltérő glükokortikoidérzékenységének szabályozásában a GR különböző mértékű expressziója játszik szerepet, melynek egyik jellegzetes példája a glükokortikoidhatás iránt rendkívül érzékeny hippocampus fokozott GR-expressziója [35].

$\mathrm{Az}$ endogén és exogén glükokortikoidok emelkedett szintje jól ismert neuropszichológiai tünetek kialakulását okozza, ami felveti az agyszövetben a de novo képződő glükokortikoidok jelentőségét ezekben a kórképekben. Rágcsálók központi idegrendszerében akut alkoholbevitel [36] vagy krónikus alkoholabúzus utáni alkoholmegvonás [37] a lokális kortikoszteronszint jelentős és régióspecifikus emelkedéséhez vezetett, változatlan plazmakortikoszteron-szint mellett. Szociális stressz hatására hasonló válaszreakciót mutattak ki [36]. Zebrapintyek fiziológiás sóoldattal történő perfúziója szintén egyes agyterületekre lokalizált kortikoszteronszint-emelkedést idézett elő, ami fokozott de novo glükokortikoidszintemelkedésre utal agyi ischaemiával és hypoxiával járó állapotokban [38]. Mindezen túl, neuroinflammatorikus kórképekben is felmerül az agyszövetben lokálisan képző- 
dő szteroidok jelentősége, a glükokortikoidoknak az astrocytasejtek növekedésére kifejtett gátló hatásán keresztül, elsősorban a hippocampalis régióban $[39,40]$.

\section{Cardiovascularis rendszer}

A cardiovascularis rendszer tekintetében, patkányokon végzett ex vivo érperfúzió során, pregnenolon kortikoszteronná történő átalakulását figyelték meg; adrenalectomiával kezelt állatokban pedig szív- és érperfúzió során a perfúziós folyadékban kimutatható volt a kortikoszteron és az aldoszteron jelenléte [41-43]. Patkányok szívében a szteroid-bioszintézishez szükséges enzimekre vonatkozó irodalmi adatok nem egységesek: egyes kutatócsoportok igazolták a StAR-, a CYPIIBI- és a $C Y P 11 B 2$-enzim expresszióját, míg további vizsgálatokban a CYPIIBI és a CYPIIB2 expressziója extrém alacsony volt, vagy nem volt kimutatható. Ugyanakkor patkányok érfalában a CYPIIAl-, a CYPIIBI és a CYPI1B2-enzim expressziója detektálható volt. Ezzel ellentétben eddigi vizsgálatok alapján egér- és csirkeszívben lokális szteroidogenezis az egyes enzimek aktivitásának hiányában nem volt igazolható $[4,5]$.

Humán szívizomszövetben a $\mathrm{P} 450_{\mathrm{c}} 1 \mathrm{l}_{\text {beta }}$ és a P450 11 AS kivételével a lokális kortikoszteroidszintézishez szükséges összes enzimet kimutatták; a P450 $11_{\text {beta }^{-}}$ enzim jelenléte kérdéses, míg a P450 11 AS-enzim csak szívinfarktusban szenvedő betegekben volt megfigyelhető. Humán érfalban szintén detektálható volt az összes enzim, azonban a $\mathrm{P} 450_{\mathrm{c}} 11_{\text {beta }}$ és a $\mathrm{P} 450_{\mathrm{c}} 11 \mathrm{AS}$ jelenléte itt is kérdéses $[4,5]$.

Az eddigi kutatási eredmények alapján az emlősök érfalában és szívében a lokálisan képződő kortikoszteroidok - leginkább az aldoszteron szintézise - bizonyos kórállapotokhoz kötött. Elsősorban szívinfarktus következtében kialakult patológiás állapotban figyelték meg a cardiovascularisan termelődő aldoszteron emelkedését. Egészséges személyek cardialis gyưjtőereiből (vena interventricularis anterior vagy sinus coronarius) nyert vérplazma aldoszterontartalma az aorta eredésénél gyújtött vérplazma aldoszterontartalmához viszonyítva nem mutatott különbséget, míg magas vérnyomásban szenvedő vagy szívinfarktuson átesett betegek plazmaaldoszteronszintje magasabb volt a szív vénáiban, mint az aortában [44, 45]. Egy másik vizsgálatban egészséges személyek plazmaaldoszteron-szintje a sinus coronariusban alacsonyabb volt, mint az aortában, míg szívinfarktuson átesett betegekben a plazmaaldoszteron-szintben nem mutatkozott különbség a kétféle lokalizációban mért érték között [46].

A cardiovascularis rendszerben történő aldoszteronszintézis szabályozásában a lokálisan képződő renin-angiotenzin rendszernek tulajdonítanak szerepet. Patkányokban létrehozott experimentális infarktus hatására fokozott renin- és angiotenzin-II-expressziót figyeltek meg, emberben szívinfarktus kapcsán pedig az angiotenzinkonvertáló enzim aktivitásának növekedését mutatták ki $[47,48]$. Mindemellett a patofiziológiás körülmények következtében lokálisan krónikusan megemelkedett aldoszteronszintézisnek szerepet tulajdonítanak az egyes szívbetegségek lefolyásában. A szívinfarktus kialakulásának kockázatát növeli a fokozott aldoszteronszintézishez társuló fibrosis és a következményes balkamra-hypertrophia kialakulása. Emellett aldoszteronantagonisták alkalmazása a szívinfarktus mortalitását jelentősen csökkentette [49].

\section{Tüdő}

A bőrszövethez és a bélszövethez hasonlóan, a külső és a belső környezet közötti egyensúly kialakításában a tüdő is nélkülözhetetlen szerepet tölt be. Az extraadrenalis szteroidtermelés vizsgálata során egerek tüdejében a glükokortikoid-bioszintézishez szükséges összes enzim jelenlétét igazolták. Hostettler és mtsai egerek tüdőszövetéből származó ex vivo sejtkultúrán fokozott kortikoszteronszintézist figyeltek meg anti-CD3-antitest, LPS és TNF $\alpha$ adását követő, in vivo immunsejt-stimuláció után [50]. Funkcionális vizsgálatok alapján azonban ezt a kortikoszteronszintézist, a lokális szteroid-bioszintézishez szükséges enzimek megléte ellenére, a HSDl 1Blenzim katalizálta, mely a hormonálisan inaktív szérumdehidrokortikoszteront hormonálisan aktív kortikoszteronná alakította át. Mindezt a HSDl1Bl-enzim fokozott aktivitása és - adrenalectomiával kezelt egerek tüdejében - az anti-CD3-antitest adását követő, de novo kortikoszteronszintézis hiánya támasztotta alá [50].

\section{Következtetések}

A kortikoszteroidszintézishez szükséges enzimek és szubsztrátok jelenlétének intenzív kutatásai alapján az extraadrenalis de novo glükokortikoidszintézis jelenléte bizonyított a thymusban, a börben és a bélrendszerben, valamint számos irodalmi adat utal a de novo szteroidszintézis lehetőségére a központi idegrendszerben, a cardiovascularis rendszerben, illetve a tüdőben. Az extraadrenalis szteroidszintézissel rendelkező szövetekben, a bioszintézishez szükséges enzimeken és szubsztrátokon túl, a szteroidszabályozásért felelős hormonok jelenléte is megfigyelhető, aminek alapján ezekben a szövetekben lokális, keringéstől független CRH-ACTH-kortizol tengely múködése is feltételezhető.

A de novo szteroid-bioszintézisre jellemző nagymértékú faji diverzitás mellett az egyes szövetek, illetve egy adott szövet egyes sejtjein belül is nagyfokú eltérést figyelhetünk meg a kortikoszteroidok termelése és szabályozása között. A szteroidogenezisre képes szövetekben a mellékvesekéreghez viszonyítva eltérô enzim- és transzkripciósfaktor-expressziót (MLN64, LRH1, P450 2D), valamint eltérő ACTH-szabályozást láthatunk. Jellemző továbbá, hogy bizonyos sejtekben a szteroidogenezis intenzitása eltérő mértékben változik az életkor előrehaladtával, valamint összefüggést mutat a sejtek fejlődési 
stádiumával is (thymocyták, thymusepithelsejtek, bélszövet-epithelsejtek).

A lokális szteroidbioszintézis kiemelt jelentőségű a szövetszintű glükokortikoidhatás szabályozásában. Úgy tûnik, hogy a mellékvesekéreg által a keringésbe juttatott kortizol elsősorban anyagcsere-folyamatok, valamint az akut stresszre adott válaszreakció szabályozásában játszik fontos szerepet, míg az extraadrenalis, de novo képződő kortizol kiemelt jelentőségü az immunszuppresszív és immunmoduláns hatásain keresztül a lokális homeosztázis fenntartásában és az immunfolyamatok szabályozásában. Mindezt alátámasztja, hogy eddigi ismereteink alapján a de novo kortikoszteroidszintézis elsődleges helye a T-sejtek differenciálódásáért felelős thymus, valamint a lokális és szisztémás immunválasz kiváltásában kulcsszerepet játszó és önálló nyirokszövettel rendelkező bőr- és bélszövet.

Anyagi támogatás: A közlemény megírása anyagi támogatásban nem részesült.

Szerzői munkamegosztás: Sz. Á., T. M. és P. A.: A téma kidolgozása. M. K., N. Zs., K. A., L. I.: A glükokortikoidreceptor funkcióinak összesítése. K. E.: Az autoimmun kórképekkel történő kapcsolat kidolgozása. A kézirat végleges változatát valamennyi szerző elolvasta és jóváhagyta.

Érdekeltségek: A szerzőknek nincsenek érdekeltségeik.

\section{Köszönetnyilvánítás}

A szerzők köszönettel és hálával gondolnak Rácz Károly professzor úrra, aki a 2000-es évek elejétől lehetőséget biztosított a laboratóriumában a glükokortikoidreceptorral kapcsolatos klinikai és transzlációs kutatások elvégzésére. A szerzők köszönetüket fejezik ki a Rácz Károly tanár úr által vezetett laboratórium korábbi, ebben a témában dolgozott PhD-hallgatóinak (Majnik Judit, Tóke Judit, Boyle Belema, Feldman Kovács Karolina, Bertalan Rita és Ács Bence) a számos tanácsért és segítségért.

\section{Irodalom}

[1] Zelena D, Makara BG. Steroids: The physiological and pharmacological effects of glucocorticoids. [Szteroidok: A glükokortikoidok élettani és gyógyszertani hatásai.] Orv Hetil. 2015; 156: 1415-1425. [Hungarian]

[2] Feldman K, Likó I, Nagy Z, et al. Importance of the $11 \beta$-hydroxysteroid dehydrogenase enzyme in clinical disorders. [A 11- $\beta$-hidroxi-szteroid-dehidrogenáz enzim jelentôsége klinikai kórképekben.] Orv Hetil. 2013; 154: 283-293. [Hungarian]

[3] Oakley RH, Cidlowski JA. Cellular processing of the glucocorticoid receptor gene and protein: new mechanisms for generating tissue-specific actions of glucocorticoids. J Biol Chem. 2011; 286: 3177-3184.

[4] Talabér G, Jondal M, Okret S. Extra-adrenal glucocorticoid synthesis: immune regulation and aspects on local organ homeostasis. Mol Cell Endocrinol. 2013; 380: 89-98.

[5] Taves MD, Gomez-Sanchez CE, Soma KK. Extra-adrenal glucocorticoids and mineralocorticoids: evidence for local synthesis, regulation, and function. Am J Physiol Endocrinol Metab. 2011; 301: E11-E24.

[6] Clark BJ, Wells J, King SR, et al. The purification, cloning, and expression of a novel luteinizing hormone-induced mitochondrial protein in MA-10 mouse Leydig tumor cells. Characterization of the steroidogenic acute regulatory protein (StAR). J Biol Chem. 1994; 269: 28314-28322.

[7] Slominski A, Zjawiony J, Wortsman J, et al. A novel pathway for sequential transformation of 7-dehydrocholesterol and expression of the P450sce system in mammalian skin. Eur J Biochem. 2004; 271: 4178-4188.

[8] Hannen RF, Michael AE, Jaulim A, et al. Steroid synthesis by primary human keratinocytes; implications for skin disease. Biochem Biophys Res Commun. 2011; 404: 62-67.

[9] Jozic I, Stojadinovic O, Kirsner RS, et al. Stressing the steroids in skin: paradox or fine-tuning? J Invest Dermatol. 2014; 134: 2869-2872.

[10] Vukelic S, Stojadinovic O, Pastar I, et al. Cortisol synthesis in epidermis is induced by IL-1 and tissue injury. J Biol Chem. 2011; 286: 10265-10275.

[11] Terao M, Katayama I. Local cortisol/corticosterone activation in skin physiology and pathology. J Dermatol Sci. 2016; 84: 11-16.

[12] Sanchis A, Alba L, Latorre V, et al. Keratinocyte-targeted overexpression of the glucocorticoid receptor delays cutaneous wound healing. PLoS ONE 2012; 7: e29701.

[13] Atanasov AG, Leiser D, Roesselet C, et al. Cell cycle-dependent regulation of extra-adrenal glucocorticoid synthesis in murine intestinal epithelial cells. FASEB J. 2008; 22: 4117-4125.

[14] Cima I, Corazza N, Dick B, et al. Intestinal epithelial cells synthesize glucocorticoids and regulate $\mathrm{T}$ cell activation. J Exp Med. 2004; 200: 1635-1646.

[15] Coste A, Dubuquoy L, Barnouin R, et al. LRH-1-mediated glucocorticoid synthesis in enterocytes protects against inflammatory bowel disease. Proc Natl Acad Sci USA 2007; 104: 1309813103.

[16] Noti M, Corazza N, Tuffin G, et al. Lipopolysaccharide induces intestinal glucocorticoid synthesis in a TNF $\alpha$-dependent manner. FASEB J. 2010; 24: 1340-1346.

[17] Mueller M, Atanasov A, Cima I, et al. Differential regulation of glucocorticoid synthesis in murine intestinal epithelial versus adrenocortical cell lines. Endocrinology 2007; 148: 1445-1453.

[18] Mueller M, Cima I, Noti M, et al. The nuclear receptor LRH-1 critically regulates extra-adrenal glucocorticoid synthesis in the intestine. J Exp Med. 2006; 203: 2057-2062.

[19] Csaba G. The role of the pineal-thymus system in the regulation of autoimmunity, aging and lifespan. [A tobozmirigycsecsemőmirigy rendszer szerepe az autoimmunitás, öregedés és élettartam szabályozásában.] Orv Hetil. 2016; 157: 1065-1070. [Hungarian]

[20] Rothenberg EV, Moore JE, Yui MA. Launching the T-cell-lineage developmental programme. Nat Rev Immunol. 2008; 8: $9-21$.

[21] Ottaviani E, Franchini A, Franceschi C. Evolution of neuroendocrine thymus: studies on POMC-derived peptides, cytokines and apoptosis in lower and higher vertebrates. J Neuroimmunol. 1997; 72: 67-74.

[22] Batanero E, de Leeuw FE, Jansen GH, et al. The neural and neuro-endocrine component of the human thymus. II. Hormone immunoreactivity. Brain Behav Immun. 1992; 6: 249264.

[23] Vacchio MS, Papadopoulos V, Ashwell JD. Steroid production in the thymus: implications for thymocyte selection. J Exp Med. 1994; 179: 1835-1846.

[24] Qiao S, Okret S, Jondal M. Thymocyte-synthesized glucocorticoids play a role in thymocyte homeostasis and are down-regulated by adrenocorticotropic hormone. Endocrinology 2009; 150: 4163-4169. 
[25] Chen Y, Qiao S, Tuckermann J. Thymus-derived glucocorticoids mediate androgen effects on thymocyte homeostasis. FASEB J. 2010; 24: 5043-5051.

[26] Qiao S, Chen L, Okret S, et al. Age-related synthesis of glucocorticoids in thymocytes. Exp Cell Res. 2008; 314: 3027-3035.

[27] Schmidt KL, Soma KK. Cortisol and corticosterone in the songbird immune and nervous systems: local vs. systemic levels during development. Am J Physiol Regul Integr Comp Physiol. 2008; 295: R103-R110.

[28] Talaber G, Jondal M, Okret S. Local glucocorticoid production in the thymus. Steroids 2015; 103: 58-63.

[29] Robel P, Baulieu EE. Neurosteroids: Biosynthesis and function. Trends Endocrinol Metab. 1994; 5: 1-8.

[30] Kishimoto W, Hiroi T, Shiraishi M, et al. Cytochrome P450 2D catalyze steroid 21-hydroxylation in the brain. Endocrinology 2004; 145: 699-705.

[31] Gomez-Sanchez EP, Ahmad N, Romero DG, et al. Is aldosterone synthesized within the rat brain? Am J Physiol Endocrinol Metab. 2005; 288: E342-E346.

[32] Ye P, Kenyon CJ, MacKenzie SM, et al. Regulation of aldosterone synthase gene expression in the rat adrenal gland and central nervous system by sodium and angiotensin II. Endocrinology 2003 ; 144: 3321-3328.

[33] MacKenzie SM, Fraser R, Connell JM, et al. Local renin-angiotensin systems and their interactions with extra-adrenal corticosteroid production. J Renin Angiotensin Aldosterone Syst. 2002; 3: 214-221.

[34] Strömstedt M, Waterman MR. Messenger RNAs encoding steroidogenic enzymes are expressed in rodent brain. Brain Res Mol Brain Res. 1995; 34: 75-88.

[35] Joëls M. Corticosteroid actions in the hippocampus. J. Neuroendocrinol. 2001; 13: 657-669.

[36] Croft AP, O'Callaghan MJ, Shaw SG, et al. Effects of minor laboratory procedures, adrenalectomy, social defeat or acute alcohol on regional brain concentrations of corticosterone. Brain Res. 2008; 1238: 12-22.

[37] Little HJ, Croft AP, O'Callaghan MJ. Selective increases in regional brain glucocorticoid: a novel effect of chronic alcohol. Neuroscience 2008; 156: 1017-1027.

[38] Taves MD, Schmidt KL, Ruhr IM, et al. Steroid concentrations in plasma, whole blood and brain: effects of saline perfusion to remove blood contamination from brain. PLoS ONE 2010; 5: el5727.

[39] Yu S, Yang S, Holsboer F, et al. Glucocorticoid regulation of astrocytic fate and function. PLoS ONE 2011; 6: e22419.

[40] Bélanger M, Magistretti PJ. The role of astroglia in neuroprotection. Dialogues Clin Neurosci. 2009; 11: 281-295.

[41] Silvestre JS, Robert V, Heymes C, et al. Myocardial production of aldosterone and corticosterone in the rat. Physiological regulation. J Biol Chem. 1998; 273: 4883-4891.

[42] Takeda Y, Miyamori I, Yoneda T, et al. Synthesis of corticosterone in the vascular wall. Endocrinology 1994; 135: 2283-2286

[43] Takeda R, Hatakeyama H, Takeda Y, et al. Aldosterone biosyn thesis and action in vascular cells. Steroids 1995; 60: 120-124.

[44] Yamamoto N, Yasue H, Mizuno Y, et al. Aldosterone is produced from ventricles in patients with essential hypertension. Hypertension 2002; 39: 958-962.

[45] Mizuno Y, Yoshimura M, Yasue H, et al. Aldosterone production is activated in failing ventricle in humans. Circulation 2001; 103 : 72-77.

[46] Tsutamoto T, Wada A, Maeda K, et al. Spironolactone inhibits the transcardiac extraction of aldosterone in patients with congestive heart failure. J Am Coll Cardiol. 2000; 36: 838-844.

[47] Passier RC, Smits JF, Verluyten MJ, et al. Expression and localization of renin and angiotensinogen in rat heart after myocardial infarction. Am J Physiol. 1996; 271: H1040-H1048.

[48] Falkenhahn M, Franke F, Bohle RM, et al. Cellular distribution of angiotensin-converting enzyme after myocardial infarction. Hypertension 1995; 25: 219-226.

[49] Pitt B, Zannad F, Remme WJ, et al., for the Randomized Aldactone Evaluation Study Investigators. The effect of spironolactone on morbidity and mortality in patients with severe heart failure. N Engl J Med. 1999; 341: 709-717.

[50] Hostettler N, Bianchi P, Gennari-Moser C, et al. Local glucocorticoid production in the mouse lung is induced by immune cell stimulation. Allergy 2012; 67: 227-234.

(Patócs Attila dr., Budapest, Szentkirályi u. 46., 1088 e-mail: patocs.attila@med.semmelweis-univ.hu)

\section{Tisztelt Szerzőink, Olvasóink!}

Az Orvosi Hetilapban megjelenő/megjelent közlemények elérhetőségére több lehetőség kínálkozik.

Rendelhető különlenyomat, melynek áráról bővebben a www.akkrt.hu honlapon (Folyóirat Szerzőknek, Különlenyomat menüpont alatt) vagy Szerkesztőségünkben tájékozódhatnak.

A közlemények megvásárolhatók pdf-formátumban is, illetve igényelhető Optional Open Article (www.oopenart.com).

Adott dij ellenében az online közlemények bárki számára hozzáférhetök honlapunkon (a közlemények külön linket kapnak, így más oldalról is linkelhetővé válnak).

Bővebb információ a hirdetes@akkrt.hu címen vagy különlenyomat rendelése esetén a Szerkesztőségtöl kérhető. 